\begin{tabular}{|c|l|}
\hline Title & A study on the enhancing earthquake frequency in northern Pakistan: is the climate change responsible? \\
\hline Author(s) & Usman, Muhammad \\
\hline Citation & $\begin{array}{l}\text { Natural Hazards, 82, 921-931 } \\
\text { https://doi.org/10.1007/s11069-016-2226-z }\end{array}$ \\
\hline Issue Date & 2016-02-17 \\
\hline Doc URL & http://hdl.handle.net/2115/64426 \\
\hline Type & article \\
\hline File Information & NHz_RevisedPaper_AcceptedV ersion.pdf \\
\hline
\end{tabular}

Instructions for use 


\title{
A Study on the Enhancing Earthquake Frequency in Northern Pakistan: Is the Climate Change Responsible?
}

\begin{abstract}
In northern Pakistan, the collision between Indian and Eurasian plates has resulted in the formation of many faults. The concentration of ruptures, in this regime, probably makes it sensitive to the localized changes in the stress. The current climate changes have caused an increase in the rainfall and variation in the mass of glaciers, present in the northern Pakistan. The rainfall and glacial runoff has potential to erode and transport sediments thus can change the balance of load across faults. On the other hand, glacial mass loss or gain also has potential of iso-static rebound or compression of crust, respectively. All these factors have been observed in the northern Pakistan. The seismic data of the duration 1965 to 2004 has been obtained from Pakistan Meteorological Department (PMD) and the sedimentation data has been acquired from Tarbela Dam Project (TDP). The study indicates a gradual increase in the earthquake frequency for the magnitudes 4.1-5.0(Mb). The epicental distributions show that these events gradually cluster in the central Karakorum and Hindukush areas. The depth analysis suggests the earthquakes with the foci 0$60 \mathrm{~km}$ are gathering in the central Karakorum and shocks with depth 0-120 are clustering in the Hindukush areas. The FMS study exhibits the dominance of normal faulting in the central Karakorum after 1999 and these characteristics do not correspond with behavior of previous mapped Raikot Fault, lying in the vicinity. The known significant variables during the study period are the different geological processes associated with climate change, which have potential to alter the load across faults and can possibly result in enhancing earthquake frequency by changing stresses at some local scale.
\end{abstract}

Key words: Climate change, glacial mass change, rising earthquake frequency

\section{Introduction}

In the present days it is an established fact that the climate is changing due to global warming. The alterations in the glacial mass, resulting from climate change, depend upon their spatial distribution through the world. Since the industrial revolution in 1750, human activities are mostly responsible for accelerated global climate changes and giving rise to other globally and locally environmental changes and alteration in land use cover and soils (Iqbal and Goheer 2008).

After Alaska and Arctic regions, the Karakorum-Himalaya $(\mathrm{K}-\mathrm{H})$ area constitutes the second largest glacial cover of the Earth (Dyurgerov and Meier 2005). On the basis of mapping done by using the recent satellite images in K-H region, the estimated glacial mass covers around 40,800 square kilometers: Himalaya 22800 and Karakoram 18000 square kilometers (T. Bolch et al. 2012). The Karakoram glaciers are fed by precipitation and avalanche. An increase in precipitation has been observed in the heights around 2500 and 4800 meters while maximum precipitation occurs at the altitude between 5000 to 6000 meters (Hewitt 2005).

A few larger glaciers are expanding in the Karakoram and adjacent areas (Smiraglia et al. 2007; Hewitt 2005). Around 5\% decline has been observed in the Karakorum glaciers in the early $20^{\text {th }}$ century (Hewitt 2011). However, the loss in mass was slowed down in 1970s (Mayewski and Jesche 1979) and in 1990s the glaciers stabilized and started advancing in the high Karakoram (Hewitt 2005; Immerzeel et al. 2009). A net gain in the glacial mass has been studied in the higher Karakoram (Naz et al. 2009). The GRACE 
satellite gravimetric observations, during 2003 to 2009, suggest a net loss in mass of glaciers across high Asian mountains, however this trend is highly variable in the space and time and northwestern part including the Karakorum mountain range show a gain in mass and in Hidukush areas there is a slight loss in mass (Matsuo and Heki 2010). During the early twentieth century i.e. 1999-2008, based on the Digital Elevation Model (DEM) data acquired from Shuttle Radar Topographic Mission (SRTM) and Satellite Pour l'Observation de la Terre (SPOT5) optical stereo imagery, J. Gardelle et al (2012) observed a slight gain in the mass, in the central Karakorum glaciers.

The snout of Baltoro glacier, one of the largest glaciers in the Karakoram, is oscillating back and forth a couple of hundred meters (Mayer et al. 2006). In the central Karakoram, there are strong indications of glacial meltdown along the northern flank of Rakaposhi Mountain and over all slight loss in the glacial mass, in the Bagrot valley (Mayer et al. 2010). As wasting ice sheets and caps unload the solid Earth, stresses released can both deform the Earth's surface (Pagli and Sigmundsson 2008) and decompress the Earth's mantle (Sigvaldason et al. 1992). The cumulative stress on the Earth's crust results from tectonic background stress, overburden pressure and pore-fluid pressure. The fault movement is controlled by the superposition of first two and variation in the third one (Twiss and Moores 2007; Steffen et al. 2013).

Along with the change in the glacial size, the stresses on the earth crust and across faults can also be altered by erosion and transport of the sediments associated with the rainfall and water runoff. To have an insight about the amount of sediments being eroded and transported from northern Pakistan, Tarbela Dam is located in ideal position. It is one of the largest rock-fill dams in the world that is built on the Indus River (Tate and Farquharson. 2000). Although it can collect some part of the rain and melt water coming from the northern Pakistan. In an average year the river Indus can carry around two hundred million tons of sediments from Himalaya and Karakoram ranges and deposits it in the Tarbela Dam (Project Monitoring Organization 1996). The sediment longitudinal profile for the Tarbela dam shows that the reservoir capacity is decreasing considerably with the each passing year (Fig. 2) due to the large amount of sediments deposited each year. The glacial mass loss and gradual increase in the rainfall would possibly result in increase discharge rate with the passage of time. So the potential of water to erode, carry, transport and deposit the sediments may also increase. The imbalance of load can have potential to change the stress regime across faults and may possibly trigger some earthquakes. Ekstro“m et al. (2006) observed an increase in the seismic activity in Greenland for the long-period seismic magnitudes in the range 4.6 to 5.1, which cannot be associated with the advancement of the instruments. The research indicated that some glaciers and ice streams periodically lurch forward with sufficient force to generate emissions of elastic waves that are recorded on seismometers worldwide.

As the northern Pakistan is thickly populated with faults, which make it sensitive to the localized changes (Usman et al. 2010b). So, this region is good to study and analyze the possible correlation between change in mass and earthquakes. Jadon (1992) proposed that the tectonically northern Pakistan is associated with the convergence resulting from the collision between Indian and Eurasian Plates and has the dominance of various types of thrust faults (Fig. 1b). The major delineated structures of the collision zone, present in the study area, are the Main Karakoram Thrust (MKT) also known as the Shyok Suture Zone, the Main Mantle Thrust (MMT) also known as the Indus Suture Zone, the Main Boundary Thrust (MBT). (Yeats and Lawrence 1984; Tahirkheli et al. 1979). The Hazara-Kashmir Syntaxis is supposed to serving as junction mainly for different types of thrust faults. The zone of about $250 \mathrm{~km}$ wide and $560 \mathrm{~km}$ long fold-and-thrust belt surrounding The Panjal-Khairabad fault (Fig. 1b) has been divided into the 
northern hinterland zone and southern foreland zone (Lisa et al. 2007). The studies also suggest that strike slip faulting is also active in this compressional zone (Verma and ChandraSekhar 1986, Sercombe et al.1998, Lisa et al. 2002, 2004).

During the probabilistic seismic hazard assessment of the northern Pakistan, Lisa et al. (2007) has observed a consistent increase in the earthquakes having moment magnitude 4.0 to 5.0. Usman et al. (2010a) proposed that the increase in the earthquake activity may possibly be the result of isostatic rebound of the earth resulting from the expected glacial mass loss due to climate change. Also, the sediment load across faults may alter the balance of load to generate earthquakes (Usman et al. 2011).

As the study area is mostly covered with glaciers and also due to the unavailability of satellite data during the study period, it is not possible to establish a direct correlation between the crust movement and the resulting seismic activity. However, it is essential to study the changing earthquake activity from every possible aspect. A revised earthquake catalog (catalogue completeness test was perfumed and unreliable events were excluded) along with sedimentation data of Tarbela Dam Project and FMS data of Global Centroid Moment Tensor (GCMT) has been used to further understand and analyze this possible relationship. The earth's climate model projections suggest that global surface air temperature will considerably increase in future due to radioactive effects of atmospheric gases (Delworth et al. 1999) which will further complicate the problem of glacier melting and associated geological hazards.

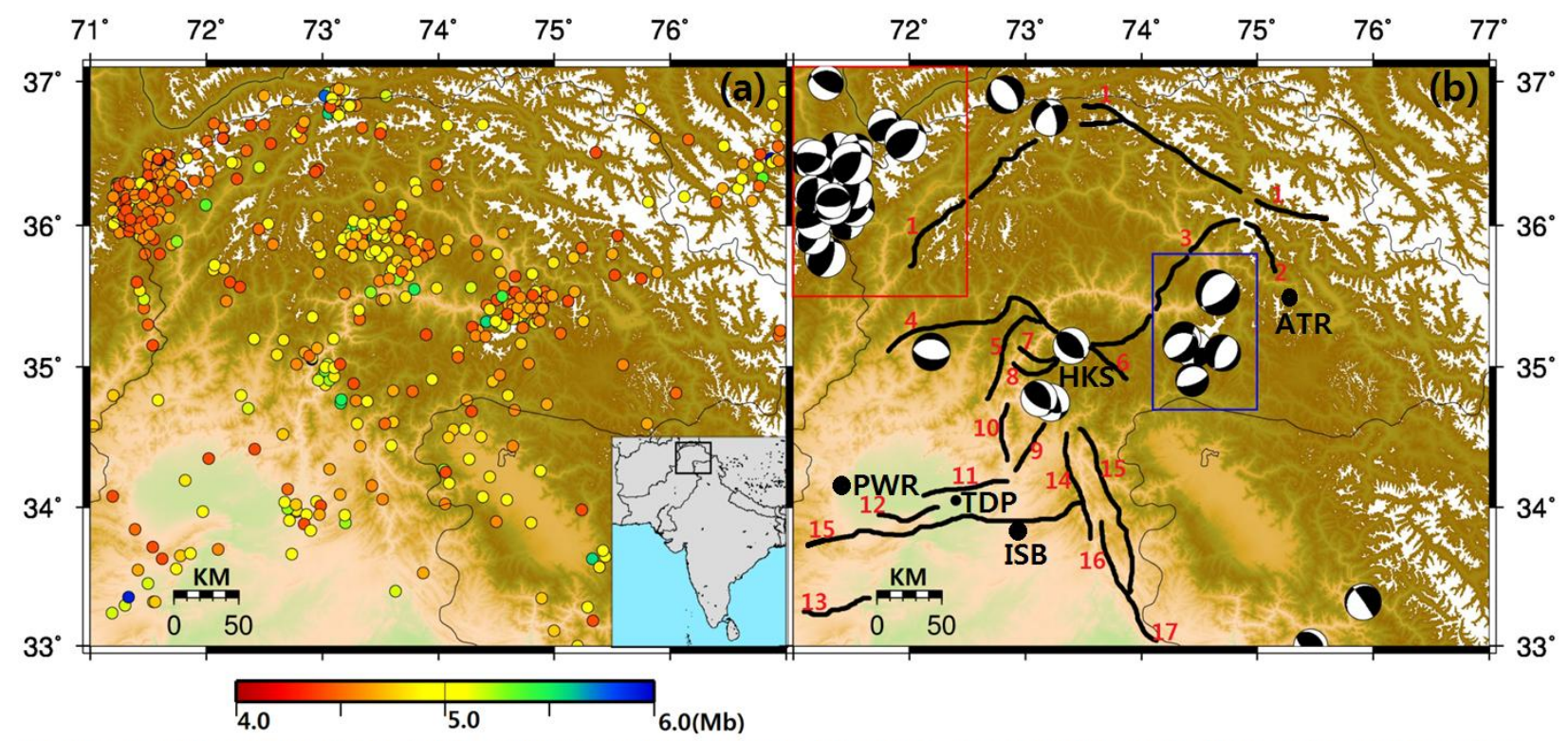

(1) Main Karakorum Thrust (2) Surghar Range Thrust (3) Raikot Fault (4) Main Mantle Thrust (5) Puran Fault (6) Batal Thrust (7) Oghi Fault (8) Mansehra Thrust (9) Panjal-Khairabad Fault (10) Darband Fault (11) Nowshera Fault (12) Kanet Fault (13) Karak Fault (14) Jehlum Fault (15) Himalayan Frontal Thrust (16) Kotli Thrust (17) Riasi Thrust (HKS) Hazara-Kasmir Syntaxis; (ATR) Astor (ISB) Islamabad (PWR) Peshawar (TDP) Tarbela Dam Project

Fig. 1 (a) The historical seismicity and the some important active faults of northern Pakistan. The colored dots, plotted by using Pakistan Meteorological data, indicate the magnitude and location of the earthquakes. (b) The faults are from Lisa et al. (2007). The beach balls are derived from Global Centeroid Moment Tensor (GCMT) data. 


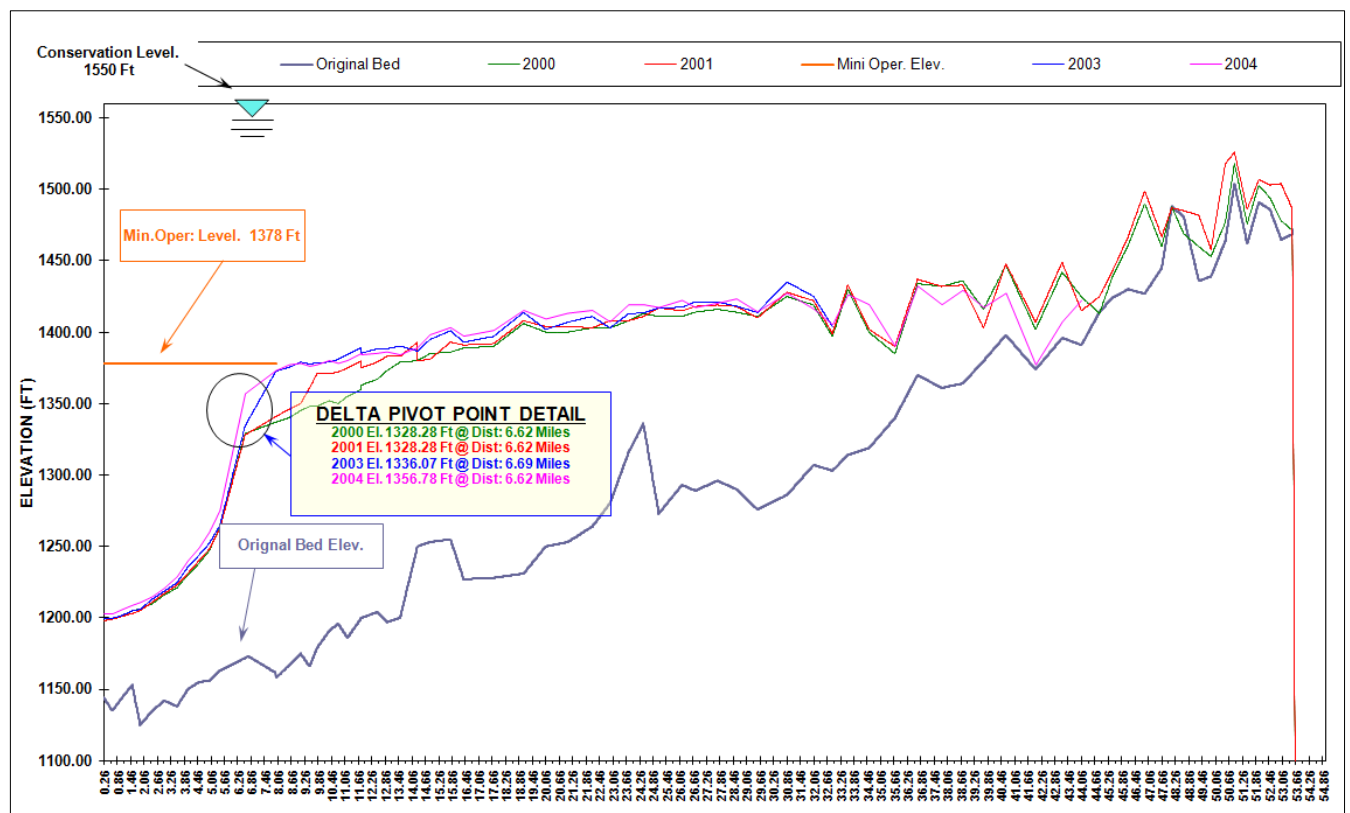

84 Fig. 2 Sediment Longitudinal Profile of Tarbela Dam. The horizontal axis shows the distance in miles (Tarbela Dam 85 Project 2010).

86

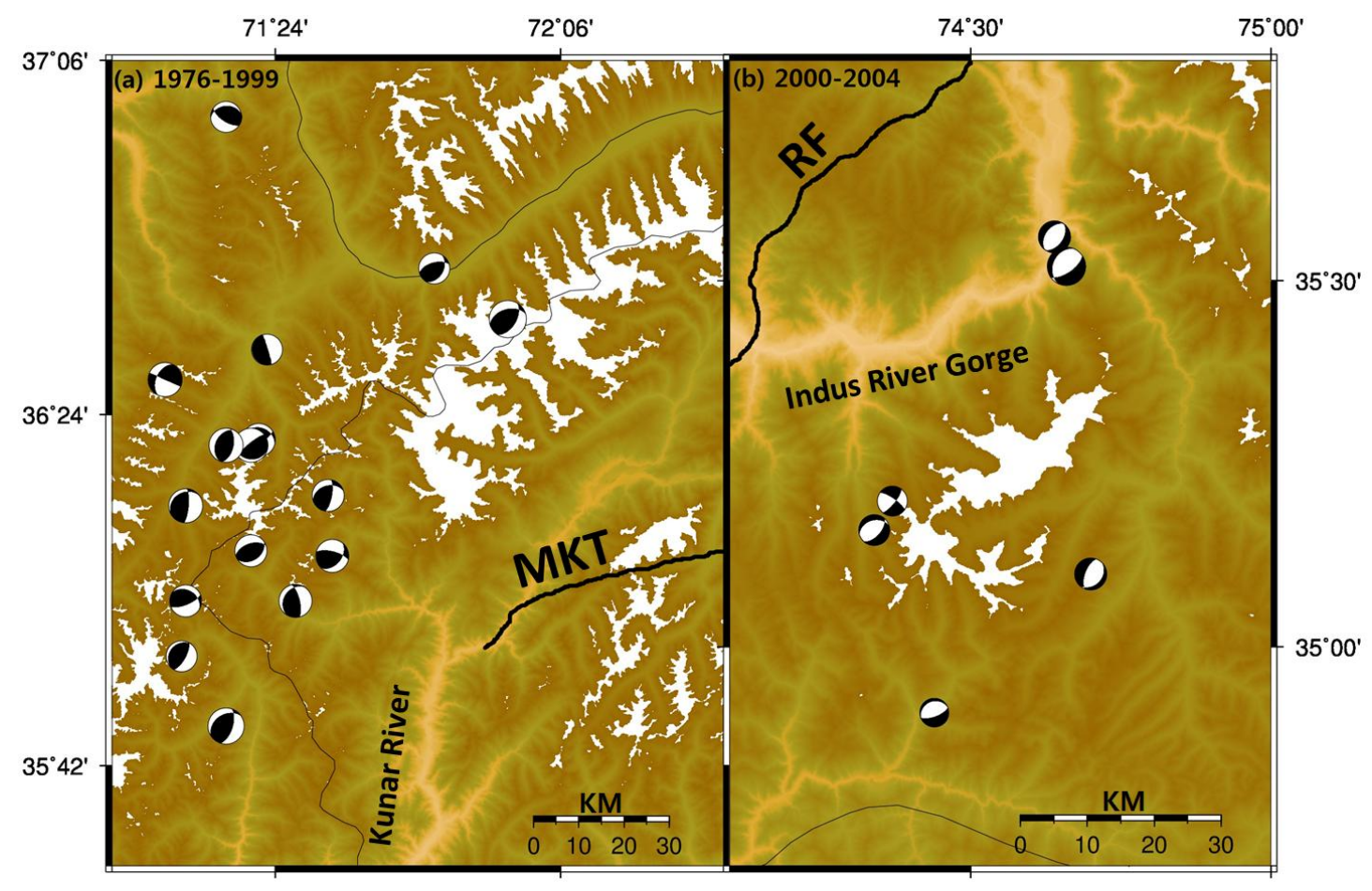

Fig. 3 Magnified view of the FMS clustered areas. MKT is Main Karakorum Thrust and RF is Raikot Fault

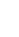

2




\section{Materials and Methods}

The seismological data was acquired from Pakistan Meteorological Department (PMD) and study duration was from 1965 to 2004 as the Pakistan has not installed new seismological stations from 19652004 in study area. Only PMD catalog was used and in this catalog every other seismological value shared from different sources like International Seismological Center (ISC), Indian Meteorological Department (IMD) etc was excluded. After performing the catalogue completeness tests (detail of the process is given in the supplementary file) the earthquakes having body wave magnitude 4.1-6.0 were selected. Although, in the northern Himalaya (including the northern Pakistan) the recurrence interval for the earthquakes having magnitude $\leq 6.0$ is less than a year (Shankar et al. 2007); but the change in load, due to climate change, is a slow geological process. So, decadal frequency has been used to make a clear conclusion. Dadson et al. (2003) also used the decal erosion rates in the eastern Central Range and southwest Taiwan, and found that the rate was the maximum in the active thrust fault regions. It means that the contribution of sediment transport in the mass change, for the active thrust region of northern Pakistan, cannot be ignored. To have an insight about the sediment transport rate and amount the sediment longitudinal profile data was acquired from Tarbela Dam Project. To examine the behavior of the earthquakes the Focal Mechanism Solutions data for the duration 1976 to 2004 was acquired from GCMT.

Table 1 Different body wave magnitude and its average frequency (AF) and cumulative frequency (CF)

\begin{tabular}{|l|r|r|r|r|r|r|}
\hline \multicolumn{1}{|c|}{ Magnitude } & $\mathbf{4 - 5 . 0}$ & AF & $\mathbf{5 . 1 - 6 . 0}$ & AF & Total & ACF \\
\hline Duration & 99 & 9.9 & 24 & 2.4 & 123 & 12.3 \\
\hline $\mathbf{1 9 6 5 - 7 4}$ & 127 & 12.7 & 5 & 0.5 & 132 & 13.2 \\
\hline $\mathbf{1 9 7 5 - 8 4}$ & 139 & 13.9 & 11 & 1.1 & 150 & 15 \\
\hline $\mathbf{1 9 8 5 - 9 4}$ & 166 & 16.6 & 11 & 1.1 & 177 & 17.7 \\
\hline $\mathbf{1 9 9 5 - 0 4}$ & 531 & 13.3 & 51 & 1.3 & 582 & 14.6 \\
\hline Total & & & & & \\
\hline
\end{tabular}

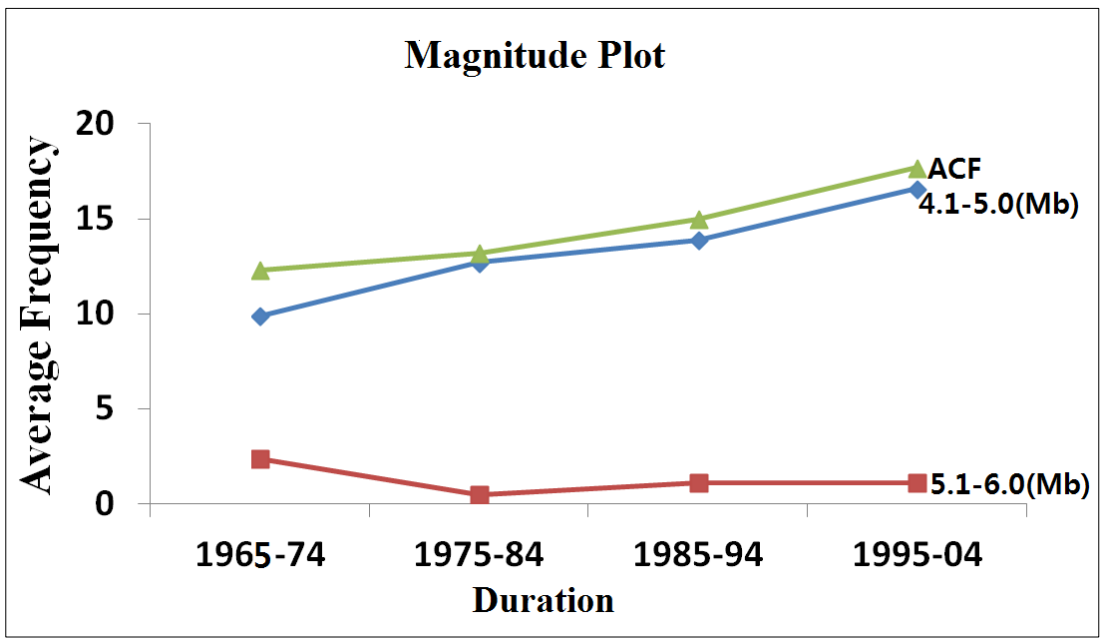

Fig. 4 Magnitude plot. ACF is Average Cumulative Frequency 


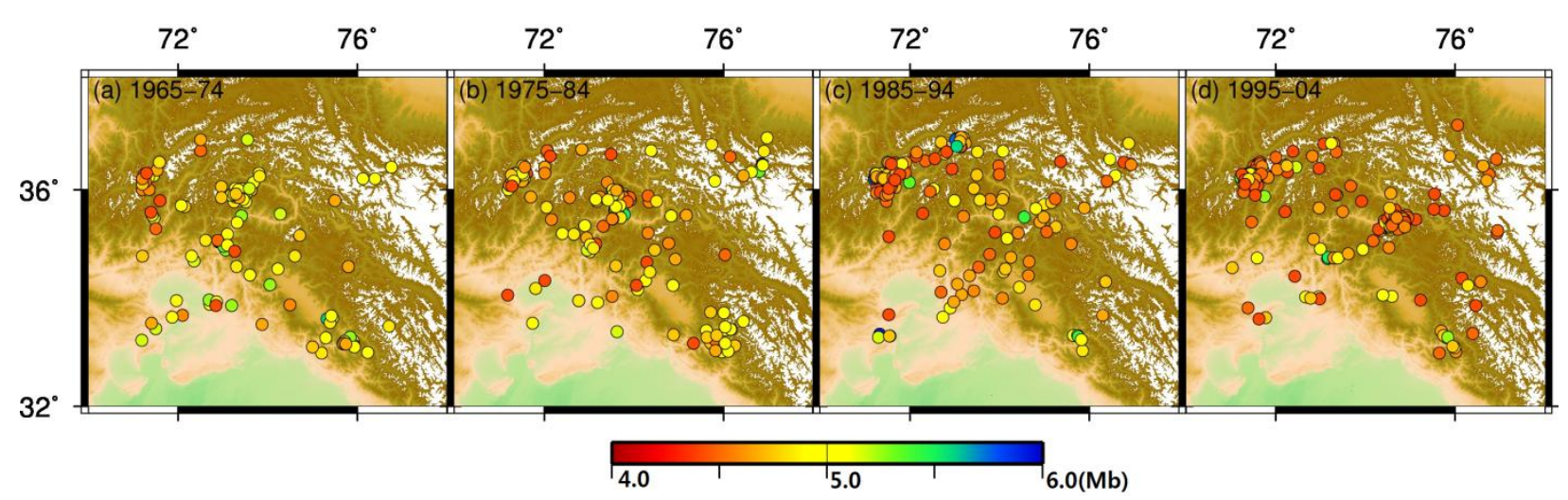

Fig. 5 Epicenteral plot for different magnitudes in the corresponding decades.

Table 2 Different depth ranges (in kilometers) and their corresponding average frequency (AF) and average

\begin{tabular}{|l|r|r|r|r|r|r|r|r|r|r|}
\hline \multicolumn{1}{|c|}{ Depth } & & & & & & & & & & \\
Duration & $\mathbf{0 - 6 0}$ & $\mathbf{A F}$ & $\mathbf{6 1 - 1 2 0}$ & $\mathbf{A F}$ & $\mathbf{1 2 1 - 1 8 0}$ & $\mathbf{A F}$ & $\mathbf{1 8 1} \boldsymbol{\mathbf { N }}$ & $\mathbf{A F}$ & Total & ACF \\
\hline $\mathbf{1 9 6 5 - 7 4}$ & 76 & 7.6 & 32 & 3.2 & 5 & 0.5 & 10 & 1 & 123 & 12.3 \\
\hline $\mathbf{1 9 7 5 - 8 4}$ & 91 & 9.1 & 36 & 3.6 & 4 & 0.4 & 1 & 0.1 & 132 & 13.2 \\
\hline $\mathbf{1 9 8 5 - 9 4}$ & 75 & 7.5 & 45 & 4.5 & 25 & 2.5 & 5 & 0.5 & 150 & 15 \\
\hline $\mathbf{1 9 9 5 - 0 4}$ & 104 & 10.4 & 51 & 5.1 & 20 & 2 & 2 & 0.2 & 177 & 17.7 \\
\hline Total & 346 & 8.7 & 164 & 4.1 & 54 & 1.4 & 18 & 0.45 & 582 & 14.6 \\
\hline
\end{tabular}

129

130

131

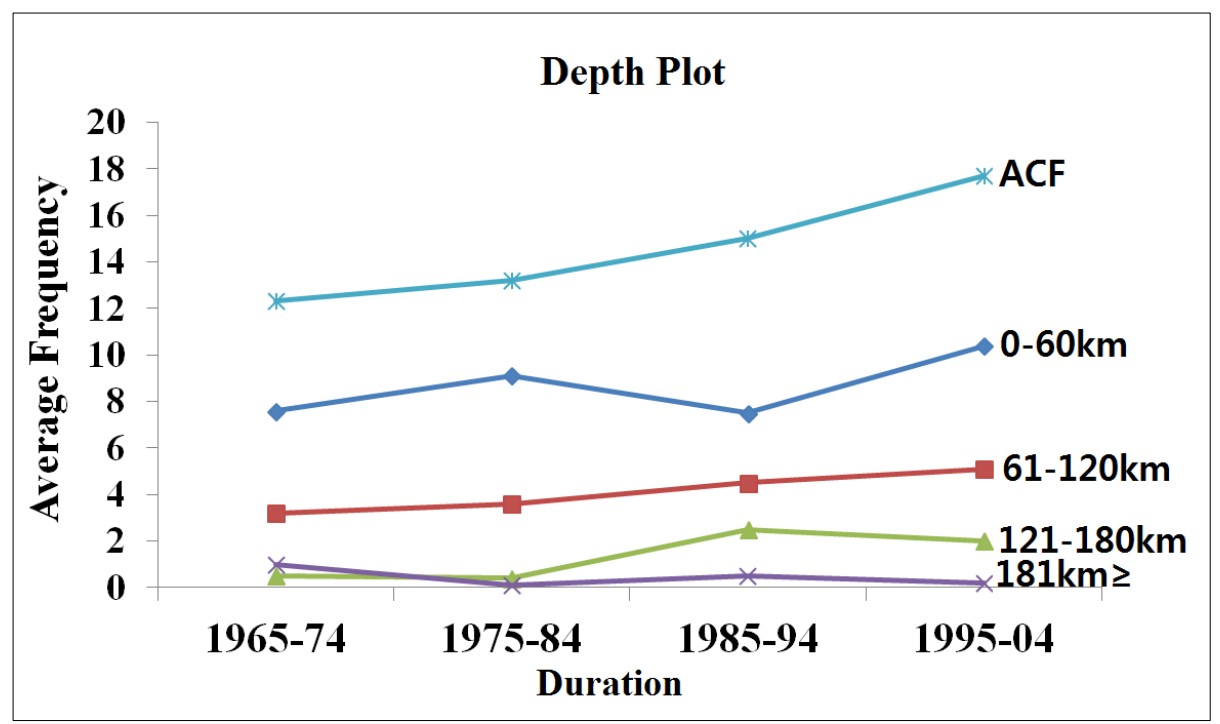

Fig. 6 Depth plot. ACF is Average Cumulative Frequency 


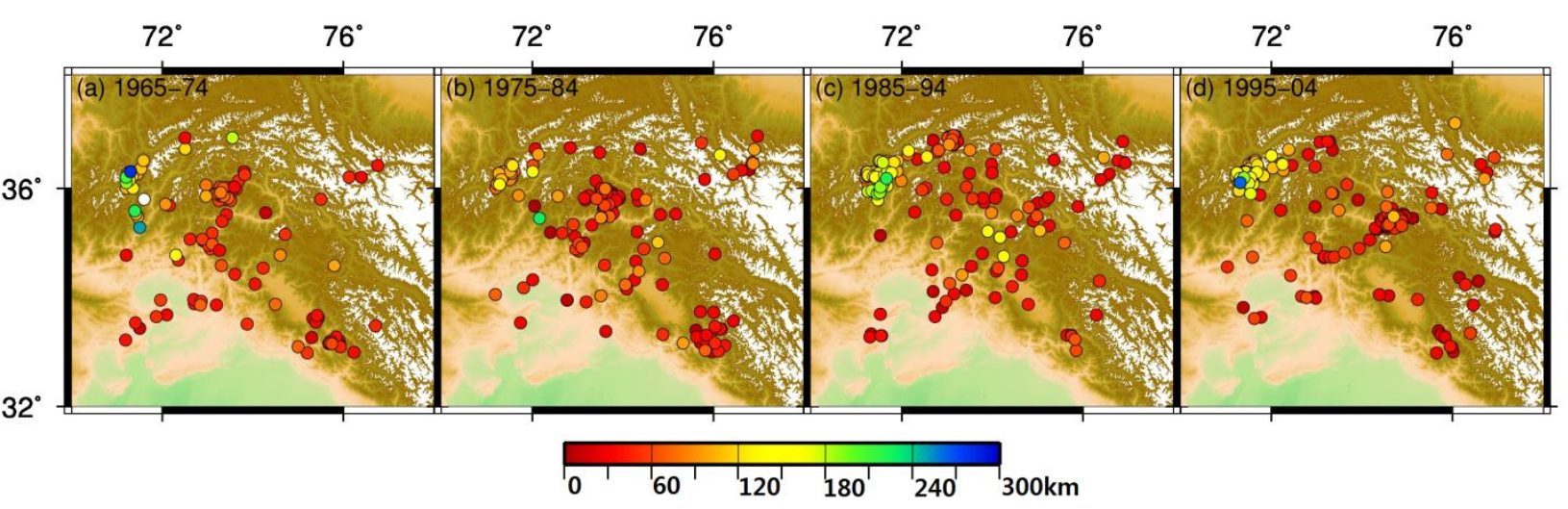

Fig. 7 Epicenteral plot for different depths in the corresponding decades.

138

139

140

141

142

143

144

145

146

147

148

149

150

151

152

153

154

155

156

157

158

159

160

161

162

163

164

165

166

167

168

\section{Results and Discussion}

Table 1 and Table 2 show the magnitude and depth wise earthquake frequency for northern Pakistan respectively. The corresponding epicenter plots for the magnitude and depth have been shown in Figs. 5 and 7. While Figs. 4 and 6 depict the average earthquake frequency for the magnitude and foci ranges, respectively.

The satellite data study of around 19 glaciers in the Hindukush area has shown that around $73 \%$ glaciers are retreating at slower rate and the study of 42 glaciers in the Karakoram areas has suggested that around $58 \%$ of the glaciers are advancing (Scherler et al. 2011). The grace gravimetric observations also indicate a slight gain in the mass of Karakoram glaciers but loss in mass has been detected in the Hindukush areas (Matsuo and Heki 2010). In the Karakoram area from 1920 to early 1990s most the glaciers have lost mass this period was punctuated with a small advancement phase in the 1970s and in the late 1990s the glaciers of Karakorum started advancing (Hewitt 2005). In the central Karakorum area, there is around 200 meters oscillation in the terminus of Baltoro glacier (Mayer et al. 2006). In the central Karakoram, there are strong indications of glacial meltdown along the northern flank of Rakaposhi Mountain and over all slight loss in the glacial mass, in the Bagrot valley (Mayer et al. 2010).

Apart from the current changes in the mass of glaciers the rain fall also has a strong potential for erosion and transportation of load across faults. In the upper Indus basin, from 1961-1999, statistical analysis shows that precipitation has increased in summers, winters and annually at several stations (Fowler and Archer 2005). Around two hundred million tons of sediments from Himalaya and Karakoram ranges are carried by Indus and deposited it in the Tarbela Dam in an average year (Project Monitoring Organization 1996) the sediment longitudinal profile is shown in Fig. 2.

So, there are strong evidences of change in mass across Karakorum and Hindukush area. As wasting ice sheets and caps unload the solid Earth, stresses released can both deform the Earth's surface (Pagli and Sigmundsson 2008) and decompress the Earth's mantle (Sigvaldason et al. 1992). For the activation of faults, the change in load over the earth crust is one of the major factors (Twiss and Moores 2007; Steffen et al. 2013). Some glaciers and ice streams periodically lurch forward with sufficient force to generate emissions of elastic waves that are recorded on seismometers worldwide (Ekstro"m et al. 2006). 
In this area as the source, stations and seismograph have remained same during the study period. The increasing temperature is causing the glaciers of study area to melt and as the glaciers melt their load on plate lessens and there is a greater likelihood of an earthquake to happen to relieve the large strain underneath (Usman et al. 2010).

The epicentral plot for different magnitude earthquake frequencies (Fig. 5) shows a 'clustering response' for the magnitude ranging from 4.1-5.0 (Mb) with passage of time in the Hindukush areas where there are reports of glacial mass loss. In the central Karakoram area where are studies indicating the change in mass and also the concentration in the earthquake epicenters for the magnitude 4.1-5.0 have been observed. Probably the combined with localized changes in the stress on the crust the glacial run off and rainfall has also the potential to erode and transport sediments across faults thus can change the balance of load and may probably trigger seismic activity. While studying the cause for the rise of Andes, Lamb and Davis (2003) concluded that climate controlled sediment starvation can possibly cause high sheer stresses along the plate boundary. The Fig. 4 shows an increase in the seismic activity for the magnitude of 4.1 to 5.0 however no such increase has been observed for 5.1-6.0 magnitude shocks. This rise in earthquake frequency was also observed by Lisa et al. (2007).

The focus plot of the epicenter (Fig. 7) also shows the clustering of earthquakes for the depth 0-60 km in the central Karakorum and around $0-120 \mathrm{~km}$ for the Hindukush areas. Also the Fig. 6 shows the increasing trend in the earthquake frequency for the depth range of 0-60 and 61-120 km. No such clear increase in earthquake frequency has been observed for the greater depths.

The Focal Mechanism study (Fig. 1b) also indicates the clustering of the events in two zones (Fig.1 a,b). Two previously studied faults are passing through these areas: Main Karakorum Thrust (MKT), strikes in strikes east-west to south-west direction; and Raikot Fault which strikes in north to north east direction (Fig. 1b). On the basis of stress directions, Seeber and Pêcher (1998) proposed that the RF is the mainly a reverse fault, although dextral and sinistral components are found locally (Seeber et al. 1997). Based on the behavior of FMS and the characteristics of MKT which is passing close, it is reasonable to believe MKT as a possible source fault in this region (Fig. 3a). From 2000 the FMS behavior seems interesting (Fig. 3b). Out of six focal mechanisms, 5 exhibit normal and one show that the strike-slip faulting. However, these characteristics do not correspond with the features of RF. Also, there is always an uncertainty about the location of FMS and they cannot be associated accurately with any under observation fault based on seismological or even the GPS data, especially in a complex tectonic regime. During the study of the October 28, 2008 shock sequence, in Baluchistan (Pakistan) based on the seismological and GPS data numerous researchers proposed that previously studied Urghaghai Fault as a possible source (Lisa and Jan 2010; Khan et al. 2008; Yadav et al. 2012). However, on the basis of synthetic aperture radar data, it became clear that a new complex geometry of conjugate faults was the responsible source (Pezzo et al. 2014; Puyssegur et al. 2014; Usman and Furuya 2015).

In the intraplate compression regime, various parts of plates experience different style of deformation and exhibit corresponding strain partitioning of reverse, normal and strike slip faulting. The FMS serve as finger prints to identify the stresses accommodation in different parts (Figs 1b, 3). The possible load change driven enhancing earthquake frequency resulting from climate change might be factor for the change of stresses at some local scale. Consequently, resulting from the increase in tremors ranging from 
4.1 to 5.0, the landslides and avalanches would possible become more frequent.

214

\section{Conclusions}

In the northern Pakistan an increase in the earthquake frequency has been observed for the magnitude 4.1 to 5.0 and epicenter plot show that they are mostly concentrated in the central Karakoram and Hindukush areas where there are reports of glacial mass change and increase in the rainfall. The depth plot indicates that the earthquakes ranging from $0-120 \mathrm{~km}$ are increasing with the passage of time while $0-60 \mathrm{~km}$ earthquakes aggregate in the central Karakorum and 0-120 km shocks show a gradual increase in the concentration in the Hindukush areas. Regardless of the fact that there is a high population of reverse faults in the central Karakorum, the FMS study indicates that from year 2000 the normal faulting is dominant in the study area and its characteristics do not correlate with the Raikot Fault passing nearby.

\section{Acknowledgments}

I am thankful to anonymous reviewers for their comments that helped to improve the manuscript. I am also incepted to Prof. Kosuke Heki and Prof. Junji Koyama for their valuable suggestions. I am very thankful to Seismic Section of Pakistan Meteorological Department and Tarbela Dam Project officials for providing the necessary data and information.

\section{References}

Al-Tarazi E. (1992) Investigation and assessment of seismic hazard in Jordan and its vicinity Ph.D. thesis, Berichte Reihe A, Inst. f. Geophysics, Ruhr-Univ. Bochum, Vol. 34.

Archer DR, Fowler HJ (2004) Spatial and temporal variations in precipitation in the Upper Indus Basin, global teleconnections and hydrological implications. Hydr \& Eart Sys Sci. 8 (1):47-61. doi: 10.5194/hess-8-47-2004
Bolch T, Kulkarni A. Kääb A, Huggel C, Paul F, Cogley JG, Frey H, Kargel JS, Fujita K, Scheel M, Bajracharya S, Stoffel M (2012) The State and Fate of Himalayan Glaciers. Sci. 336, 310:310-314. doi: 10.1126/science. 1215828

Dadson SJ et al. (2003) Links between erosion, runoff variability and seismicity in the Taiwan orogen. Nature. Vol: 426

Delworth T, Mahlman JD, Knutson TR (1999) Changes in summer temperature and heat related mortality since 1971 in North Carolina, South Finland, and Southeast England.Environ Res. 91:1-7.doi: 10.1016/S0013$\underline{9351(02) 00002-6}$

Dyurgerov MB, Meier MF(2005) Glaciers and the Changing Earth System: A 2004 Snapshot. http://instaar.colorado.edu/uploads/occasional-papers/OP58_dyurgerov_meier.pdf. University of Colorado at Boulder. Accessed April 2011

Ekstro“m G, Nettles M, Tsai VC (2006) Seasonality and Increasing Frequency of Greenland Glacial Earthquakes. Science.336:1756-1758. doi: 10.1126/science.1122112

Fowler HJ, Archer DR (2005) Hydro-climatological variability in the Upper Indus Basin and implications for water resources. Regional Hydrological Impacts of Climatic Change-Impact Assessment and Decision 
Making. Proceedings of symposium S6 held during the Seventh IAHS Scientific Assembly at Foz do Iguaçu, Brazil.

Gardelle J, Berthier E, Arnaud Y (2012) Slight mass gain of Karakoram glaciers in the early twenty-first century. Nat Geosci. 5:322-325.doi:10.1038/NGEO1450

Hewitt K (2005) The Karakoram Anomaly? Glacial Expansion and 'Elevation Effect,' Karakoram Himalaya. :Mount Res and Devel. 25:pp332-340. doi; http://dx.doi.org/10.1659/02764741(2005)025[0332:TKAGEA]2.0.CO;2

Hewitt K. (2011) Glacier Change, Concentration and Elevation Effects in the Karakoram Himalaya, Upper Indus Basin.Moun Res and Devel. 31:188-200.doi: http://dx.doi.org/10.1659/MRD-JOURNAL-D-11-00020.1

Iqbal MM, Goheer MA (2008) Greenhouse Gas Emission from Agro-Ecosystems and Their Contribution to Environmental Change in the Indus Basin of Pakistan. Adv in Atm Sci. 25: 1043-1052.

Immerzeel WW, Droogers P, de Jong SM, Bierkens MFP (2009) Large-scalemonitoring of snow cover and runoff simulation in Himalayan river basins using remote sensing. Rem Sen of Env.113:40-49. doi: $\underline{10.1016 / \text { j.rse.2008.08.010 }}$

Jadoon IAK. (1992). Thin-skinned tectonics on continent/ocean transitional crust, Sulaiman Range, Pakistan. Ph.D. thesis, Oregon State University, USA.

Khan MA et al (2008) Preliminary geodetic constraints on plate boundary deformation on the western edge of the Indian plate from TriGGnet (Tri-University GPS Geodesy Network). J Himayan Geoscience. 41:71-87

Kazmi AH, Jan MQ (1997) Geology and Tectonics of Pakistan . In: Neotectonics. Graphic Publishers, Karachi.Pakistan

Lamb S, Davis P, (2003) Cenozoic climate change as a possible cause for the rise of the Andes. Nature. Vol: 425. pp 792-797. doi:10.1038/nature02049

Lisa M, Jan MQ (2010) Geoseismological study of the Ziarat (Balochistan) earthquake (doublet?) of 28 October 2008. Current Sciences. 98(1):50-57

Lisa M, Khwaja AA, Javed M, Ansari YS, Jan MQ (2005) Seismic Hazard Assessment of NW Himalayan Fold and Thrust Belt, Pakistan, Using Probabilistic Approach. Proceedings of Pakistan Academy of Sciences. 42(4). pp 287-295

Lisa M, Khwaja AA, Qaiser M. (2002) Focal Mechanism Studies of Kohat and Northern Potwar Deformed Zone.Geo.1 Bul. Univ. of Peshawar 35 85-95.

Lisa M, Khan SA, Khwaja AA. (2004) Focal Mechanism Studies of North Potwar Deformed Zone (NPDZ) Pakistan. Acta Seismol. Sinica. 17(3), 255-261.

Lisa M, Khwaja AA, Jan MQ (2007) Seismic Hazard Assessment of the NW Himalayan Fold-and-Thrust Belt, Pakistan, Using Probabilistic Approach. Journal of Earthquake Engineering. DOI: $10.1080 / 13632460601031243$

Mahmood N, Hara T (2008) Travel time residuals from the new and old networks of Pakistan and preliminary hypocenter determination. . International Institute of Seismology and Earthquake Engineering.(Japan). Available at http://iisee.kenken.go.jp/syndb/?action=abstr\&id=MEE07163\&est=S\&year=2008

Matsuo K, Heki K (2010) Time-variable ice loss in Asian high mountains from satellite gravimetry. Ear and Planet Sci Let. 290:30-36. doi:10.1016/j.epsl.2009.11.053 
Makropoulos KC, Burton PW (1981) A catalogue of seismicity in Greece and adjacent areas. Geophysical Journal International. 65. pp 741-762.

Mayer C, Lambrecht A,Belo M , SmiragliaC, Diolaiuti G, (2006) Glaciological characteristics of the ablation zone of Baltoro glacier, Karakoram, Pakistan. Annals of Glaciology 43:123-131

Mayer C, Lambrecht A, Mihalcia C, Belo M ,Diolaiuti G, Smiraglia C, Bashir F (2010) Analysis of Glacier Melt Water in Bagrot Valley Karakoram. Mou Res and Devel 30(2):169177.doi : http://dx.doi.org/10.1659/MRD-JOURNAL-D-09-00043.1

Mayewski PA, Jeschke PA (1979) Himalayan and trans-Himalayan glacier fluctuations since AD 1812. Arc and Alp Res. 11:267-287.

Naz BS, Bowling LC, Diffenbaugh NS, Owens P, Ashfaq M, Shafiqur-Rehman S (2009) Hydrological sensitivity of the Upper Indus River to glacier changes in the Karakoram Himalaya region. Poster no. C31C0455 presented at the American Geophysical Union Meeting. San Francisco, CA, November 2009.

Pakistan's Water and Power Development Authority (WAPDA) (Project Monitoring Organization, 1996) Project Monitoring Organization: 1996, Reservoir Sedimentation Report, Tarbela, Pakistan.

Pakistan Meteorological Department (PMD) NOSAR (Norway) (Report 2007) Seismic Hazard Analysis and Zonation for Pakistan, Azad Jammu and Kashmir. Available at http://www.pmd.gov.pk/seismicreport_pmd.pdf

Pagli C, Sigmundsson F (2008) Will present day glacier retreat increase volcanic activity? Stress induced by recent glacier retreat and its effect on magmatism at the Vatnajökull ice cap, Iceland. Geophy Res Let 35:1-5 doi: 10.1029/2008GL033510

Pezzo G, Bancori JPM, Atroz S, Antonioli A, Salvi S (2014) Deformation of the western Indian plate boundary: insights from differential and multi-aperture InSAR data inversion for the 2008 Baluchistan (Western Pakistan) seismic sequence. Geophysical Journal International. doi:10.1093/gji/ggu106 Pinel-

Puysségur B, Grandin R, Bollinger L, Baudry C (2014) Multifaulting in a tectonic syntaxis revealed by InSAR: the case of the Ziarat earthquake sequence (Pakistan). Journal of Geophysical Research Solid Earth. 119:58385854. doi:10.1002/ 2013JB010564

Sercombe W J, Pivnik DA, Wilson, WP, Albertin ML, Beck RA, Stratton MA (1998) Wrench Faulting in the northern Pakistan foreland. AAPG Bulletin 82, 2003-2030.

Sarwar F, Iqbal S, Kamal S (2011) An Analysis of Pakistan's Local Network Catalog of Earthquake for the Period of1905-2007. Science International. 23(1), 13-18.

Scherler D, Bookhagen B, Strecker MR (2011) Spatially variable response of Himalayan glaciers to climate change affected by debris cover. Nature Geoscience. vol: 4. pp 156-159. doi: 10.1038/NGEO1068

Seeber L, Armbruster JG, Meltzer AS, Beaudoin BC, Zeitler PK (1997) Extension above shortening from earthquakes in the Nanga Parbat massif [abs.]: Eos Transactions, American Geophysical Union, v. 78, p. F651.

Seeber L, Pecher A (1998) Strain partitioning along the Himalayan arc and the Nanga Parbat antiform. Geology. v. 26; no. 9. pp 791-794

Smiraglia C, Mayer C, Mihalcea C, Diolaiuti G, Belò M, Vassena G (2007) Ongoing variations of Himalayan and Karakoram glaciers as witnesses of global changes: Recent studies of selected glaciers. Devel in Ear Surf 
Proc. 10:235-248. doi: doi:10.1016/S0928-2025(06)10026-7

Shankar D, Yadav RBS, Singh HN (2007) On the seismic risk in the Hindukush-Pamir-Himalaya and their vicinity. Current Science. Vol:92 pp 1625-1630

Sigvaldason GE, Annertz K, Nilsson M (1992) Effect of glacier loading/deloading on volcanism: postglacial volcanic production rate of the Dyngjufjöll area, central Iceland. Bull of Vol 54: 385-392.

Steffen R, Wu P, Steffen H, Eaton DW (2013) On the implementation of faults in finite-element glacial isostatic adjustment models. Computers \& Geosciences. 62(2014) 150-159. doi: http://dx.doi.org/10.1016/j.cageo.2013.06.012

Stepp JC (1973) Analysis of completeness of the earthquake sample in the Puget Sound area. Contributions to seismic zoning, NOAA Tech. Report, ERL 267-ESL 30, Washington, D.C. pp. 16-28.

Tarbela Dam Project (2010) Sedimentation Profile. Courtesy: Hydrological and Sedimentation (H\&S) Department.

Tate EL, Farquharson FAK (2000) Simulating Reservoir Management under the Threat of Sedimentation: The Case of Tarbela Dam on the River Indus. Water Resources Management 14: 191-208,

Twiss RJ, Moores EM (2007) Structural Geology, 2nd ed. W.H. Freeman and Company, New York, USA.

Usman M, Zafar M, Murata M, Amir NA (2010b) Effects of Temperature Increase on Earthquake Frequency and Depth in Northern Pakistan. International Conference on Biology, Environment and Chemistry. IPCBEE vol.1. IACSIT Press, Singapore

Usman M, Asghar ZA, Saeed A,Rafi Z ( 2011) A Study on Enhancing Earthquake Frequency in the Glacial and Planar of Areas of Pakistan with Emphasis on Magnitude. Am Jour of Sci Res: July :155-156

Usman M, Qureshi SN, Amir NA (2010a) Effects of Global Warming on the Frequency of Earthquakes in Northern Areas of Pakistan. Sci Vis. 15:39-50

Usman M, Furuya M (2015) Complex faulting in the Quetta Syntaxis: fault source modeling of the October 28, 2008 earthquake sequence in Baluchistan, Pakistan, based on ALOS/PALSAR InSAR data. Earth, Planets and Space. DOI 10.1186/s40623-015-0303-2

Tahirkheli RAK, Mattauer M, Proust F, Tapponier P. (1979) The India-Eurasia suture zone in northern Pakistan: Some new data for interpretation at plate scale. Geodynamics of Pakistan. Farah A. DeJong KA. Eds. Geol. Surv. Pak. Quetta, pp. 125-130.

Verma RK, ChandraSekhar C (1986) Focal mechanism solutions and nature of plate movements in Pakistan. Jour. Geodyn 5. 331-351.

Yadav RBS, Gahalaut VK, Chopra S, Shan B (2012) Tectonic implications and seismicity triggering during the 2008 Baluchistan, Pakistan earthquake sequence. Journal of Asian Earth Sciences. 45:167-178. doi:10.1785/0120120133

Yeats RS, Lawrence RD (1984). Tectonics of the Himalayan thrust belt in northern Pakistan. Marine Geology and Oceanography of Arabian Sea and Coastal Pakistan, Haq, BU \& Milliman, J. D. Van Nostrad Reinhold Co., New York, pp. 177-200. 